\title{
Genus Quesnelia (Bromeliaceae, Bromelioideae) of Paraná State, Brazil
}

\author{
Fernanda Maria Cordeiro de Oliveira ${ }^{1,2}$ \& Rosângela Capuano Tardivo ${ }^{1}$
}

\begin{abstract}
Quesnelia is a genus of the subfamily Bromelioideae (Bromeliaceae) with 20 species endemic to Brazil occurring from the south portion of the state of Bahia to the northern portion of the state of Santa Catarina. Quesnelia is subdivided into two subgenera: Quesnelia subg. Quesnelia and Quesnelia subg. Billbergiopsis. The purpose of this work was to conduct a taxonomic study of Quesnelia species from Paraná state (southern Brazil) along with morphological and taxonomic analysis of in vivo material and specimens in herbaria collections. Three taxa were found: Quesnelia humilis, Q. imbricata and $Q$. testudo. This work presents identification keys, morphological descriptions, geographical distribution, comments, illustrations and the conservation status of the studied taxa.

Key words: flora, monocotyledons, Southern Brazil.

Resumo

Quesnelia pertence à subfamília Bromelioideae (Bromeliaceae) com 20 espécies, endêmicas do Brasil ocorrendo desde o sul da Bahia até o norte de Santa Catarina, enquadradas em dois subgêneros: Quesnelia subg. Quesnelia e Quesnelia subg. Billbergiopsis. Um estudo taxonômico do gênero para o Paraná foi realizado, consistindo de pesquisa bibliográfica, estudo morfológico e taxonômico de material in vivo e de exemplares das coleções de diversos herbários. São reconhecidos três táxons: Quesnelia humilis, Q. imbricata e Q. testudo. Chaves de identificação, descrições morfológicas, distribuição geográfica, comentários, ilustrações e o status de conservação dos táxons estudados são apresentados.
\end{abstract}

Palavras-chave: flora, monocotiledôneas, Sul do Brasil.

\section{Introduction}

The Bromeliaceae Juss. family comprises 58 genera and 3352 species (Luther 2012). It is found nearly exclusively in the Neotropics from the southern portion of North America to the region of Patagonia, in South America. The exception is Pitcairnia feliciana (A. Chev.) Harms \& Mild, which occurs in western Africa as the result of a recent dispersal event (Givnish et al. 2011). Brazil is one of the centers of diversity for the family, as it harbors $70 \%$ of the genera ( $22 \%$ endemic to the country) and approximately 1200 species (BFG 2015). Thirtyone genera are found in the Atlantic Forest, ten of which are endemic to this phytogeographic domain, including the genus Quesnelia (Martinelli et al. 2008).

The family is currently divided into eight subfamilies (Bromelioideae, Tillandsoideae Harms, Pitcairnoideae Harms, Navioideae Harms, Puyoideae Givnish, Brocchinioideae Givnish, Hechtioideae
Givnish and Lindmanioideae Givnish), which are monophyletically assembled based on molecular characters (Givnish et al. 2007; Givnish et al. 2011). The genus Quesnelia Gaudich. belongs to the subfamily Bromelioideae, which is characterized by possessing a serrate leaf, inferior ovary, berry-like fruit and considerable morphological variability. This subfamily includes more than half of the genera of Bromeliaceae (Benzing 2000), with 32 genera and approximately 800 species (Schulte et al. 2009). The genus is traditionally delimited by the presence of simple inflorescences, sepals that are non-connate to mildly connate at their base and biporate pollen grains (Smith \& Downs 1979).

Quesnelia was established by GaudichaudBeaupré (1842). The type species is Q. rufa Gaudich. The author also considered Quesnelia to be closely related to the genus Billbergia Thunb. due to the morphological similarity between the two taxa.

\footnotetext{
${ }^{1}$ Universidade Estadual de Ponta Grossa, Dep. General Biology, Av. Gal. Carlos Cavalcanti, 4748, Ponta Grossa, PR, Brazil.

${ }^{2}$ Author for correspondence: fercordeirobio@gmail.com
} 
Mez (1892) subordinated Quesnelia to the tribe Bromelieae Baker, subtribe Porateae Mez. The author was the first to question Quesnelia as a valid genus, mentioning the affinity of the taxa to species of Aechmea and Billbergia. While admitting the artificiality of the genus, Mez (1896) maintained its previous taxonomic position and divided it into three subgenera: Quesnelia subg. Billbergiopsis Mez, Quesnelia subg. Quesnelia and Quesnelia subg. Wawraea Mez. The author also discussed the affinity between species of the subgenus Quesnelia and those of Aechmea subg. Pothuava, and pointed out the morphological similarities between species of subgenus Billbergiopsis and those of Billbergia. Mez (1934) emphasized the pollinic similarity between Quesnelia and Aechmea, and differentiated the two by the shape of the ovules, which are obtuse in Quesnelia and caudate in Aechmea, as well as by the simple inflorescence found in Quesnelia and the compound inflorescence in Aechmea.

In the most recent revision of Bromeliaceae, Smith \& Downs (1979) considered only two subgenera (Quesnelia and Billbergiopsis), differentiated mainly by the simple, dense, strobilate to cylindrical inflorescence in Quesnelia and the dense or lax, simple or compound inflorescences in Billbergiopsis. The authors subordinated 14 species to the genus.

Almeida et al. (2009) performed a phylogenetic analysis of the genus Quesnelia through morphological characters. The study included taxa from six genera of the subfamily Bromelioideae. Quesnelia emerged as a polyphyletic group, closely related to the genera Aechmea and Billbergia. The subgenus Quesnelia emerged as monophyletic, with a high degree of similarity among the species analyzed, whereas the subgenus Billbergiopsis emerged as polyphyletic with considerable affinity to the genera Aechmea and Billbergia. More recently, Evans et al. (2015) performed a phylogenetic analysis with chloroplast DNA sequence data within Bromelioideae. According to the authors, Quesnelia emerges on a large polytomy with others Bromelioideae genera (Billbergia, Aechmea, Canistropsis, Nidularium) forming the 'Billbergia-nidularioid' clade.

The genus Quesnelia has been studied in Brazil following the conception adopted by Smith \& Downs (1979). Reitz (1983) only cited Q. imbricata L.B.Sm. as found in the state of Santa Catarina and the author also reported the occurrence of this species in the state of Paraná. Fontoura et al. (1991) report the presence of eight species of Quesnelia in Rio de Janeiro state, with both $Q$. edmundoi L.B.Sm and Q. lateralis Wawra endemics to that state. Proença et al. (2007) report five species of Quesnelia in São Paulo state, among which only $Q$. violacea Wand \& S.L. Proença would be endemic. According to BFG (2015), 23 species of Quesnelia occur throughout the Atlantic Forest in Brazil from the eastern portion of Bahia state to Santa Catarina state. All of these species are considered to be endemic (Martinelli et al. 2008).

A previous study of Vascular Plants in Paraná State shows that 107 species of Bromeliaceae occur in this state. There are 20 genera being Vriesea ( 28 spp.), Dyckia (20spp.) and Tillandsia (17 spp.) the most representative ones (Tardivo 2014). Giving continuity to the taxonomic study of Bromeliaceae in Paraná state, this work provides a study on Quesnelia contributing with information for future systematic studies of this genus in Brazil.

\section{Materials and Methods}

A bibliographic survey was carried out on Quesnelia Gaudich. Further information was obtained through classical studies specific to the family: Wawra (1880), Mez (1892, 1934), Smith \& Downs (1979), Reitz (1983), Benzing (2000) and Luther (2012).

All collected material was processed following usual techniques in plant taxonomy (Radford et al. 1974; Judd et al. 2009). Subsequently these plants were deposited in the Herbarium of the Ponta Grossa State University (HUPG). For the morphological and taxonomic studies, we also consulted specimens from the following herbaria: EFC, FUEL, HBR, HUEM, HUPG, MBM, SP and UPCB (the acronyms of which are based on Thiers (continuously updated).

The material was analyzed under a stereomicroscope. Identification was based on Smith \& Downs (1979), Proença et al. (2007) and original descriptions, as well as on the analysis of photographs of the holotypes when available online. The specific terminology for the morphological descriptions was based on Stearn (1983) and Gonçalves \& Lorenzi (2011). The work of Weberling (1989) was used for the types of inflorescence and the work of Brown \& Gilmartin (1989) was used for the nomenclature of the stigma.

The conservation status of the taxa studied in Paraná state was based on the criteria and categories established by the International Union for Conservation of Nature (IUCN 2010). 


\section{Results and Discussion}

Taxonomic treatment

Quesnelia Gaudich. Voyage autour de Monde éxécuté pendant les Années 1836 et 1837 sur la Corvette la Bonite, Botanique: 54. 1842. Typus: Quesnelia rufa Gaudich. Brazil, Rio de Janeiro, fl., no date, Gaudichaud 370 (Holotype: P [image!]).

Herbs, epiphytic, humicolous, terricolous on sandy land, saxicolous or rupicolous, $30-110 \mathrm{~cm}$ long, but some can get $2 \mathrm{~m}$, with short or rarely long stalk. Infundibular, tubulous or ellipsoid rosette, forming a tank. Leaves, 4 to 6 , or numerous, ca. 50 , distichous or spiral, papiraceous or coriaceous, lepidots in both sides, with distinction between the sheath and the blade; sheaths with entire margins, oblong to wide-elliptic; blade ligulate, ensiform or strict-triangular, with margins sparsaly spinulose, prickly with thick and curved spines, apex roundedapiculate to strict acute. Floral peduncle well developed, emerging from the center of the rosette or lateral at the plant basis, erect, sub-pendulum or curved with white lanuginous, glabrously or rarely lepidote; peduncle bracts broad, well developed, spiraled, laxa or imbricate, involving completely the peduncle, the apex ending in a rigid spine; or stricts bracts, laxaly imbricates with apex without spine. Inflorescence simple, forming spike, with polistic flowers at the principal axis or rarely few branched, with few or many series, erect or pendulous. Floral bracts always presents, conspicuous, broad and showy, imbricate, involving completely the ovary, covering the petals, oblong, piriphormes, ovatecuculate or triangulal, papiraceous, subcoriaceous or membranaceous, pink, green-yellow, red or yellow. Flowers androgynous, sessils; sepals asymmetrics or sub-symetrics, free or lightly conate at the basis, ecarenate or rarely carenete, apex rounded, obtusus, acute, acuminated-mucronated, pink, cream, yellow, red or purple; petals symmetrics, free, usually erects to sub-curved, oblong, lightly obovate or spatulate, apex rounded, curved, with 2 petal appendages at the basis, spatulate, infundibuliformis, serreted or fimbriated, usually with 2 callosities long with the internal fillet, white with the apex in blue or purple, cream, yellow, violete, dark blue or sky blue; stamens in two series, the first free, the second adnate at the petals for more than half part, shorter than the petals; fillets filiform, complanet; anthers dorsifixe, incluse or sub-incluse to exertes; ovary inferous, tube epigineous developed, 2-7 $\mathrm{mm}$, styles filiphormis, forming at the apex three stigmatic branch; ovules obtusus, anatrops or short apiculate, numerous. Fruit berry, subtrigonous or cilindric, with varied coloration, seed numerous.

Quesnelia Gaudich. is endemic to Brazil, distributed along the eastern coast in the Atlantic Forest biome from the state of Bahia to the state of Santa Catarina (BFG 2015).

\section{Identification key of Quesnelia Gaudich. species to Paraná State}

1. Rosette with 35-46 leaves; inflorescence strobilate, congest, 100-115 flowers. Peduncle bracts papiraceous. Equal floral bracts, showy, larger than sepals 1. Quesnelia testudo

1'. Rosette with 10-18 leaves. Inflorescence spike, lax, 10-20 flowers. Peduncle bracts membranaceous. Floral bracts dimorphic, the lower conspicuous, showy and larger than the sepals, the uppers inconspicous and smaller than sepals.

2. Rupicolous plants, with tubular rosette. Peduncle bracts lanceolate with apiculate apex. Petals with retuse erect apex and petal appendages entire at the base, fimbriated at the apex

2. Quesnelia imbricata

2'. Epiphytic, humicolous plants, mesophytics with open rosette. Peduncle bracts ecliptics, with acute apex. Petals with emarginated apex, cuculate and petals appendages fimbriated from the basis at the apex 3. Quesnelia humilis

1. Quesnelia testudo Lindm., Kongliga Svenska Vetenskapsakademiens Handlingar III. 24(8): 24, t. 3, f. 9-19. 1891. Typus: Brazil, São Paulo (Sorocaba, Santos) 1.IV.1875, Mosen 2976 (Holotype S, Foto GH). $\quad$ Figs. 1; 2; 3 Herb epiphyte or terricolous $90-110 \mathrm{~cm}$ high, forming clumps. Long rhizome, ca. $15 \mathrm{~cm}$ long, $1.5-2 \mathrm{~cm}$ in diameter, not branched, with internodes larger than $1 \mathrm{~cm}$. Leaves 35-46, ca. $50 \mathrm{~cm}$ long, rosulate, forming an wide rosette with a tank in the basis, serrate at the margins, lepidote in both sides; sheaths ca. $16 \times 7.5 \mathrm{~cm}$, ovate, lightly vinaceous; blades 30-43 $\times 4.3 \mathrm{~cm}$, oblong, green, acuminate apex. Floral peduncle 


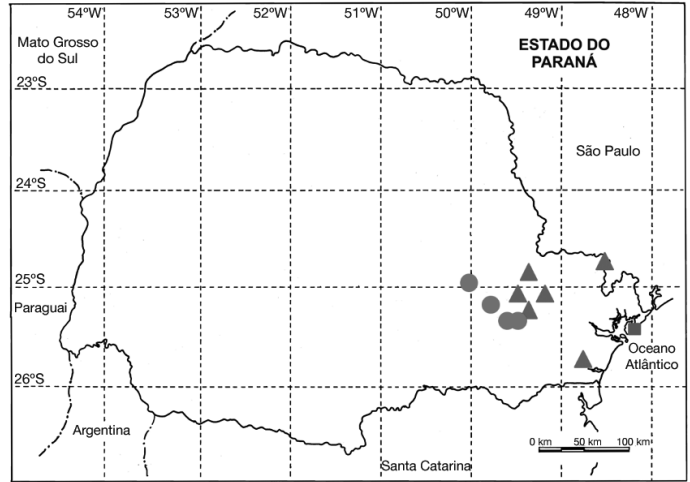

Figure 1 - Geographic distribution of Quesnelia Gaudich. genus in Paraná State. Quesnelia testudo Lindm, $\boldsymbol{\Delta}$ Quesnelia imbricata L.B.Sm. and Quesnelia humilis Mez.

erect, $30 \mathrm{~cm}$ long, $1.5-2.2 \mathrm{~cm}$ diameter, emerging the rosette, lightly lanuginous; peduncle bracts ca. $8.5 \times 3.5 \mathrm{~cm}$, oblong, lightly green, papyraceous, slightly serreted margin at the top, strongly intertwined, involving the peduncle, obtuse-acuminate apex. Inflorescence ca. 10 $\times 6 \mathrm{~cm}$, densely strobilate, $100-115$ polistic flowers; floral bracts equal to each other, showy, larger than the sepals, ca. $3.3 \times 1.7 \mathrm{~cm}$, oblong, concave basis with an hyaline margin, lightly lanuginous at abaxial face, pink, slightly serreted margin at the top, with apiculate apex. Flowers sessile, ca. $3 \mathrm{~cm}$ long, sepals ca. 1.2 $\times 0.6 \mathrm{~cm}$, symmetric, ovate, with an involute membranaceous margin, lightly lanuginous; petals ca. $2 \times 0.7 \mathrm{~cm}$, erects, linear, with two basal petal appendages spatulate, emarginate apex, rounded, cuculated, purple, with nectar guide sharp, irregularly dentate at the apex, cuneiform; stamens ca. $1.8 \mathrm{~cm}$ long, in two series, the first united with the petals by ca. 1.2 $\mathrm{cm}$ long, the second free, anthers ca. $7 \mathrm{~mm}$ long, lanceolete, dorsifixed; ovary ca. $1.3 \mathrm{~cm}$ long, $1 \mathrm{~cm}$ diameter, ovoid, trine, white in the basis, lightly pink at the apex, densely lanuginous, epigynous tube ca. $2 \mathrm{~mm}$ long, ovules $\infty$, style ca. $2.5 \mathrm{~cm}$ long, stigma conduplicate-spiral.

Material examined: Guaraqueçaba, Ilha de Superagui, 10.VII.1997, fl., L.R.M. Souza \& E. Santana 227 (FUEL); 19.IV.1994, fl., R.C. Tardivo \& J.O. Mendonça 169 (MBM, UPCB); Trilha da Restinga 13.VII.2011, fl., F.M.C. Oliveira et al. 14 (HUPG); Restinga da Praia Deserta, fl., 27.V.1998, G. Martinelli et al. 15031 (MBM); Restinga da Praia Deserta, fl., 13.VII.2011, F.M.C. Oliveira et al. 16 (HUPG).
Adicional material: BRAZIL. SÃO PAULO: Barra da Uma, Rodovia Bertioga- São Sebastião, 24.IX.1962, fl., J. Lattos 10613 (SP). Caraguatatuba, Parque Estadual da Serra do Mar, 12.XI.1999, fl., G. Martinelli et al. 15897 (SP). Paranapiacaba, Estação Biológica, 18.X.1983, fl., A. Custódio Filho 1671 (SP); 16.X.1984, fl., M. Sugiyama et al. 559 (SP); 2.XII.1977, fl., M.G.L. Wanderley 72 (SP). Peruíbe, Estação Ecológica JuréiaItatins, fl., 29.V.1996, L.P. de Queiroz \& R. Belinello 4534 (SP). Registro, fl., 12.X.1961, L. Seidel 286 (HBR); Santo André, Reserva Biológica do Alto da Serra de Paranapiacaba, fl., 5.XI.1985, M. Kirizawa \& A.E. Lopes 1561 (SP); fl., 26.XI.1980, E.A. Lopes \& J.M.Pires 82 (SP); fl., 26.XI.1980, N.A. Rosa \& J.M. Pires 3944 (SP). São Paulo, fl., B.A. Moreira (SP382078). Ubatuba, fl., 15.IX.2004, M.G.L Wanderley \& C. Ameixeiro 2451 (SP); Alto da Serra, Estação Biológica, fl., 4.II.1921, F.C. Hoehne (SP -7542).

Quesnelia testudo is distributed in the states of São Paulo and Paraná, Brazil. In Paraná, it occurs in the municipality of Guaraqueçaba on Ilha de Superagui and in Ilha das Peças in a dense rainforest. According to the IUCN this species is classified as vulnerable (VU) due to its restricted distribution in environmental protection areas. Blooms can be found from May to July; fruits are found from August to September.

Martinelli et al. (2008) cited Q. testudo and $Q$. arvensis as present in the state of Paraná, in Guaraqueçaba on Ilha de Superagui. However, the study of different specimens collected from the same site reveals that the populations in this region belong to a single taxon - identified here as $Q$. testudo Lindm. based on the original description as well as on field observations and on the analysis of several specimens in herbarium collections.

Quesnelia testudo belongs to the subgenus Quesnelia. Species of this subgenus exhibit considerable morphological affinities to each other, constituting a monophyletically sustained clade (Almeida et al. 2009). However, the morphological similarities have lead to a number of erroneous identifications. Quesnelia testudo is differentiated from other species in the state of Paraná by its foliar rosette formed by a large number of leaves (35 to 46) and the strobilate inflorescence formed by a large number of flowers (100 to 115$)$.

Among the species of the subgenus, $Q$. testudo is most similar to $Q$. arvensis (Vell.) Mez. The two taxa can be differentiated by the variation in the type of margin of the floral bracts (Smith \& Downs 1979). Proença et al. (2007) 

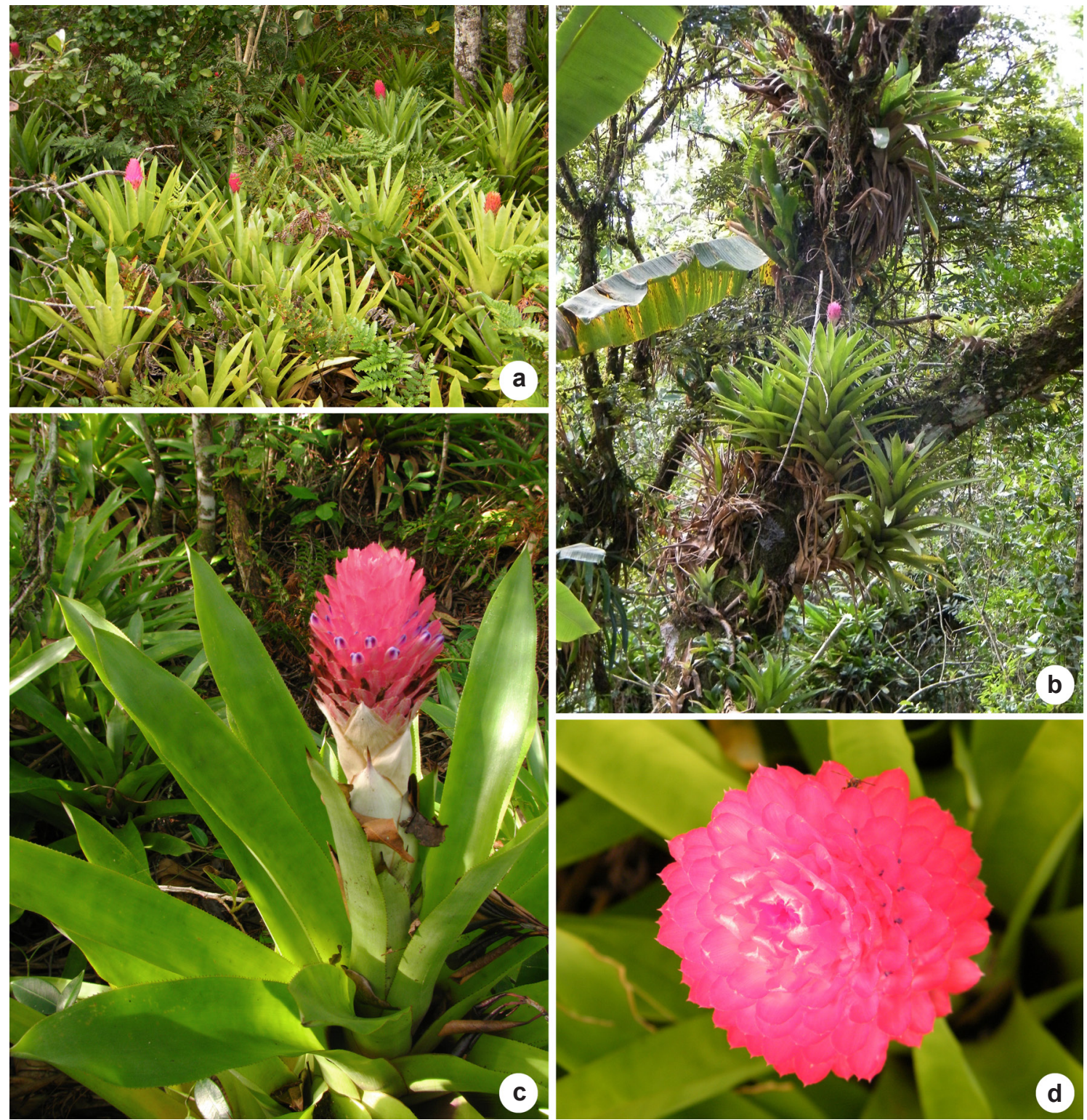

Figure 2-Quesnelia testudo Lindm. - a. terricolous habit; b. epiphytic habit; c. detail of strobiliformis inflorescence with pink attractive floral bracts and flowers with white petals and purple apex; d. superior view of inflorescence.

differentiate the two species by the presence of a sheath on the floral bracts of $Q$. arvensis. Specimens of Q. testudo collected in Paraná state exhibit intermediary characteristics to those reported by the aforementioned authors.

The analysis of several specimens of $Q$. testudo and Q. arvensis from the states of Rio de Janeiro and São Paulo revealed that the two species are separated by the variation in the size of the floral bract, which was also observed by Smith \& Downs
(1979). However, this morphological difference alone cannot be considered to be an adequate character for differentiation. As we could see in species from São Paulo and Rio de Janeiro state, this is a very plastic character in the subgenus Quesnelia. More investigations, such as phylogeographic, morphometry and population genetic studies involving different populations throughout the entire geographic distribution of the taxa could clarify the nomenclatural problem of the group. 


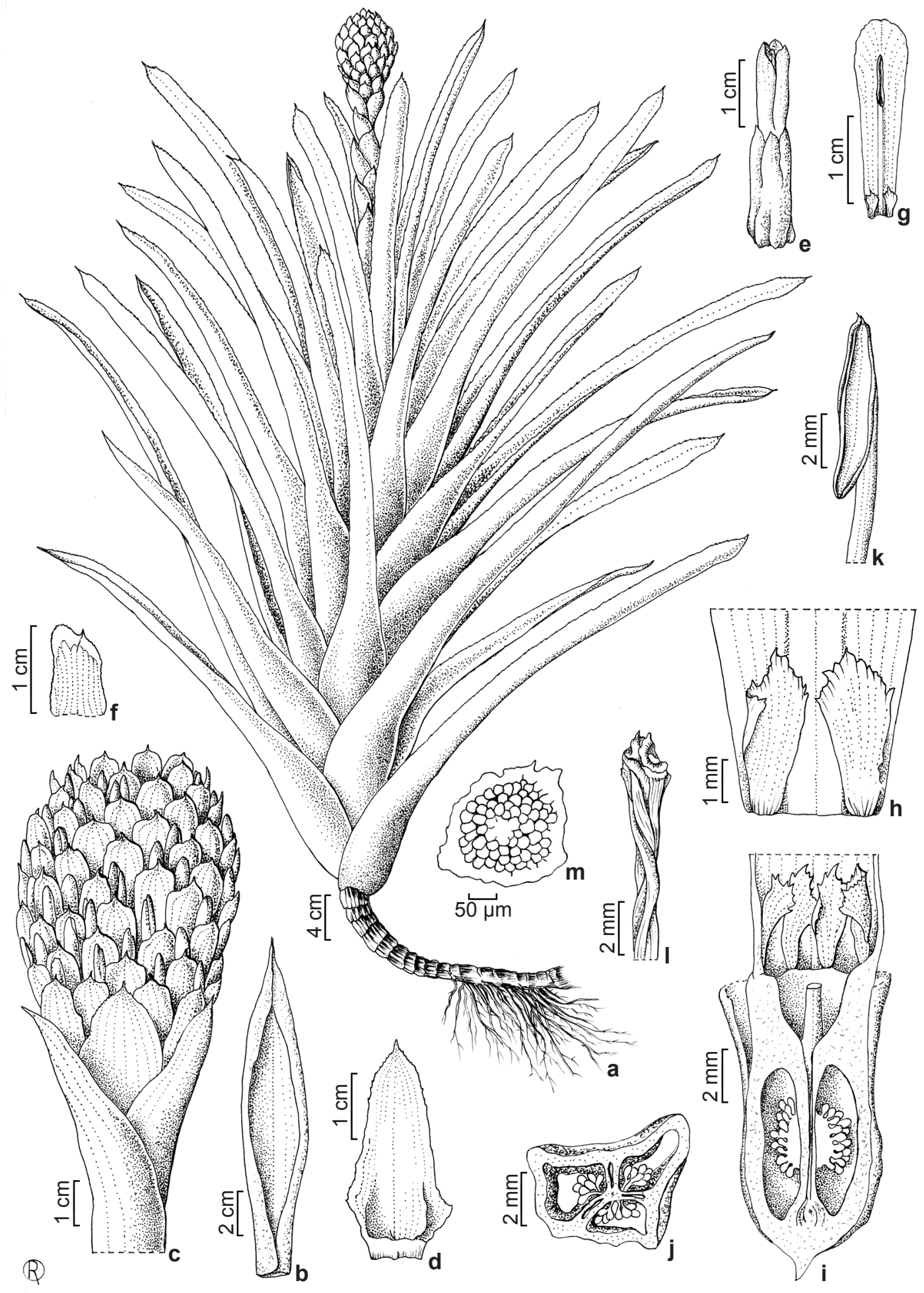

Figure 3 - Quesnelia testudo Lindm (Oliveira, F.M.C 14) - a. plant habit; b. peduncle bract; c. inflorescence; d. floral bract; e. flower; f. sepal; g. petal; h. basal petal appendix details; i. longitudinal section of ovary showing the ovules and epigenous tube; $j$. cross section of ovary; $\mathrm{k}$. lateral view of anther; 1 . stigma; $\mathrm{m}$. peltate trichome with disc cells and ring cells arranged in irregular form. 
2. Quesnelia imbricata L.B.Sm Arquivos de Botânica do Estado de São Paulo II. 2: 195, t. 63. 1952. Typus: Brazil, Paraná (Campo Largo), 26.VIII.1939, Foster 405 (Holotype GH [image!], Isotype R [image!], US image [!]).

Figs. 1; 4a-d; 5

Herb rupicolous, 40-48.5 cm long, forming clumps, xerophytic. Short rhizome, ca. $2.5 \mathrm{~cm}$ long, $1 \mathrm{~cm}$ diameter, not branched, with inconspicuous internodes. Leaves 12-18, rosulate, erects, forming a tubulous rosette, ca. $11 \mathrm{~cm}$ diameter, serrate at the top, lepidote, the external $26 \times 6 \mathrm{~cm}$; the internal $45 \times 5 \mathrm{~cm}$; sheaths clear, $16-20 \times 5.5 \mathrm{~cm}$, ovate, vinaceous; blade $10-30 \times 2.5-3.5 \mathrm{~cm}$, oblong, green, mucrunate apex with purple spots. Floral peduncle ca. $33 \mathrm{~cm}$ long, $1-1.5 \mathrm{~cm}$ diameter, lightly curved at the top, exceeding the length of the rosette, lightly lanouginous; peduncle bracts ca. $9 \times 2.5 \mathrm{~cm}$, evolving completely the peduncle, imbricate, lanceolate, membranaceous, pink, apiculate apex. Inflorescence 5.9-11 × 2.1-5 cm, simple, laxa, spike, $10-18$ polistic flowers, floral bracts dimorphic, the lower ca. $4 \times 0.8 \mathrm{~cm}$, oblong, pink, acute apex; the upper ca. $1.3-0.3 \mathrm{~cm}$, lineartriangular, pink, acute apex. Flowers sessile, ca. 3.7 cm long; sepals ca. $1.4 \times 0.5 \mathrm{~cm}$, linear-triangular, involute at the right margin, free, pink, acute apex; petals ca. $2.8 \times 0.8 \mathrm{~cm}$, spatulate, free, erects, pink, blades with an pair of longitudinal callosities to ca. $1.8 \mathrm{~cm}$ long, two basal petals appendages, entire at the base, fimbriated at the apex, retuse apex,; stamens in two series, ca. $2.7 \mathrm{~cm}$ long, the first united at the petals by ca. $1.3 \mathrm{~cm}$, the second free, fillet with hyaline margins flattened, anthers $5 \mathrm{~mm}$ long, lanceolate, dorsifixe; ovary ca. $0.9 \times 0.5 \mathrm{~cm}$, oval, trine, pink, epigynous tube ca. $3 \mathrm{~mm}$, ovules $\infty$, style ca. $2.5 \mathrm{~cm}$, stigma conduplicate-spiral imbricate.

Examined material: Campina Grande do Sul, Morro Capivari Grande, fl., 11.VII.1996, F. Galvão \& R.C. Tardivo 50 (EFC), Picadão do Rio Pardinho, Serra Negra, fl., 24.III.1963, G. Hatschbach 10004 (MBM); Pico Caratuva, fl., 2.VIII.1967, G. Hatschbach \& H. Haas 16831 (MBM); Ribeirão do Mundéo, fl., 22.I.1960, G. Hatschbach 6725 (MBM); Serra do Capivari, Pico Capivari Médio, fl., 16.VIII.2009, Voltz 52 (UPCB); Serra dos Órgãos, fl., 16.X.1990, A.P. Tramujas 179 (EFC); Guaratuba, Serra de Araçatuba, Morro dos Perdidos, fl., 27.IV.2011, F.M.C. Oliveira et at. 3 (HUPG); f1., 29.VI.2011, F.M.C. Oliveira \& S.N.A. Miyamoto 6 (HUPG); fl., 9.XI.1994, C.B. Poliquesi \& J. Cordeiro 240 (MBM); Morro dos Perdidos, fl., 10.XII.1998, E.P. Santos et al. 705 (MBM-UPCB); f1., 15.IX.1995, J.M. Silva \& C.B. Poliquesi 1499
(MBM); fl., 8.VIII.1997, J.M. Silva \& O.S. Ribas 2014 (MBM); fl., 12.V.1998, E.P. Santos, A. da L. Sanches \& L.C. Candido 476 (UPCB); Piraquara, Morro Albino Souza, 5.IX.1948, G. Hatschbach 1016 (MBM); Quatro Barras, Serra da Baitaca, fl., 24.X.1996, J. Cordeiro \& E. Barbosa 1352 (MBM); Morro Anhangava, fl., 26.X.2011, F.M.C. Oliveira et al. (HUPG); Tijucas do Sul, Serra do Araçatuba, fl., 19.VII.1992, A.P. Tramujas 604 (EFC); Serra do Papanduva, fl., 4.XII.2003, E. Barbosa \& J.M. Silva 819 (MBM).

Additional material: BRAZIL. SANTA CATARINA: Garuva, Morro do Campo Alegre, fl., 23.III.1961, Reitz \& Klein 10974 (HBR); Morro do Iquereri, fl., 31.VIII.1961, R. Reitz 6740 (HBR); Morro do Iquereri, fl., 9-10. XII.1965, L.B.Smith 8555 (HBR).

Quesnelia imbricata L.B.Sm. has a restricted distribution to Southern Brazil. In Paraná state it occurs on the first plateau and also on the coast in regions of mixed rainforest. According to IUCN this species is classified as vulnerable (VU) because of its distribution (only at high altitudes in areas of difficult access, in environmental protection areas and state parks). On the other hand, this distribution confers greater protection to the species. Blooms can be found from March to August; fruit found from August to December.

Quesnelia imbricata is characterized by a tubular rosette with densely imbricated leaves. It is exclusively rupicolous and found only at sites above $1400 \mathrm{~m}$, forming dense populations.

Quesnelia imbricata resembles $Q$. humilis Mez. by their spike inflorescence and the pink coloration of their flowers. Morphological similarities led to erroneous identification for many years, with material cited by Smith \& Downs (1979) and Reitz (1983).

This species is recognizable by its small size (maximum height: $48.5 \mathrm{~cm}$ ); evident, strongly vinaceous sheath on the adaxial face; and the tubular rosette. The geographic distribution of the species at high altitudes is also an important factor to its recognition. Almeida et al. (2009) demonstrated the proximity of $Q$. humilis and $Q$. imbricata based on morphological characters.

3. Quesnelia humilis Mez C.F.P.von Martius \& auct. suc. (eds.), Fl. Bras. 3(3): 386 (1892). Typus: Brazil, Rio de Janeiro, Quinta da Boa vista, 1887, Glaziou 16434 (Holotype, B [image!]; Isotype: P; foto: F).

Figs. 1; 4e-h; 6

Herb epiphyte, humicolous or terricolous, 50-80 cm long, forming clumps, mesophytic. Short rhizome, $3-5 \mathrm{~cm}$ long, $1-1.5 \mathrm{~cm}$ diameter, with inconspicuous internodes. Leaves 10-15, 

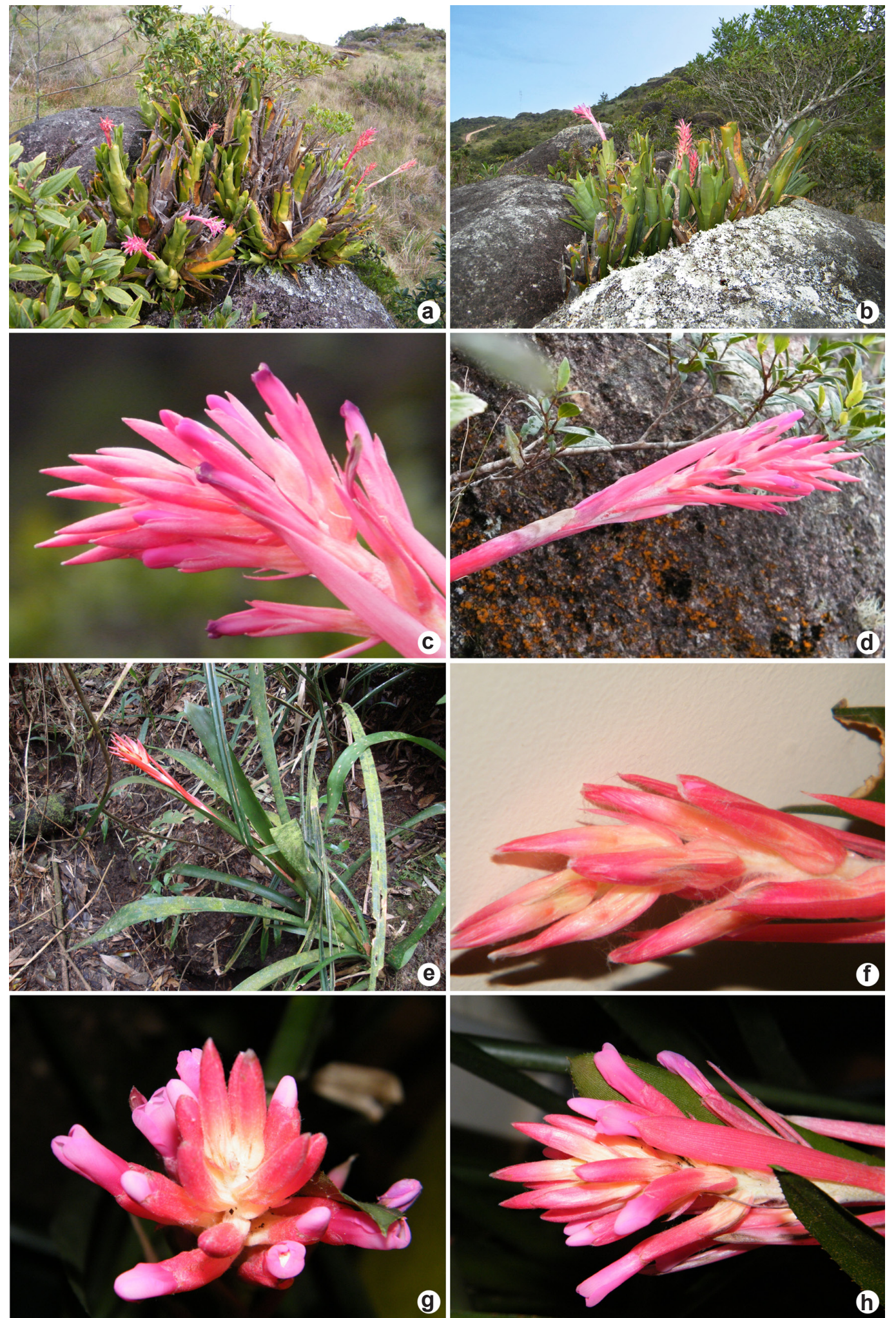

Figura 4-a-d. Quesnelia imbricata L.B.Sm. - a-b. rupicolous habit, forming dense clumps; c-d. details of spike inflorescence, showing dimorphic floral bracts. e-h. Quesnelia humilis Mez.-e. terricolous habit; f. details of spike inflorescence, showing dimorphic floral bracts; $\mathrm{g}$. frontal view of inflorescence; $h$. lateral view of inflorescence, anthesis details. 


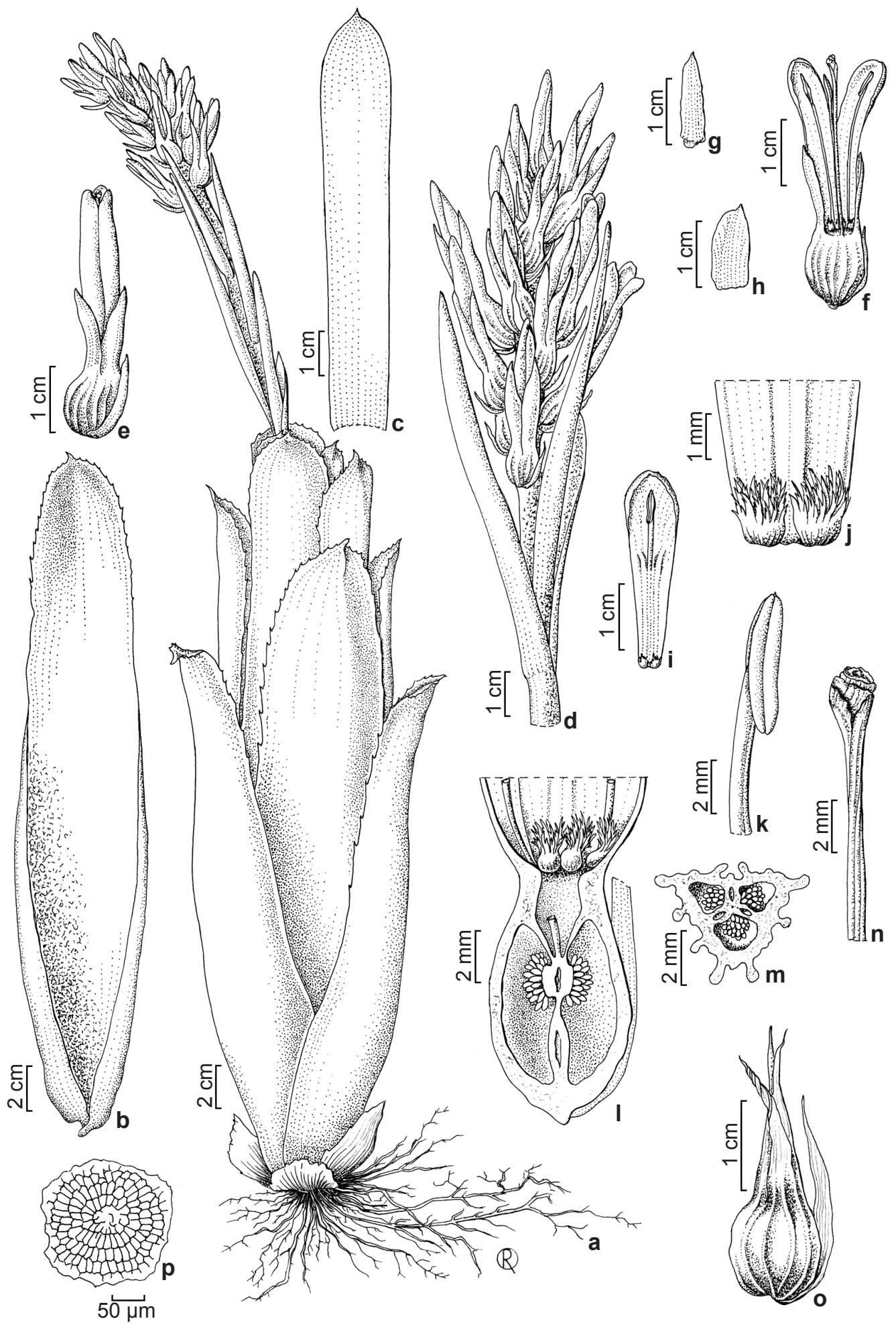

Figure 5-Quesnelia imbricata L.B.Sm. (Oliveira, F.M.C. 7) - a. plant habit; b. adaxial view of leaf; c. peduncle bracts; d. inflorescense detail; e. lateral view of flower; f. open flower; g. superior floral bract; $h$. sepals; i. petals; $j$. basal petal appendages and longitudinal callosities details; $\mathrm{k}$. anthers; 1 . longitudinal section of ovary showing the ovules and epigeneus tube; $\mathrm{m}$. cross section of trigonal ovary; $n$. stigma; $\mathrm{o}$. fruits; $\mathrm{p}$. peltate trichome with disc cells and ring cells arranged in irregular form. 


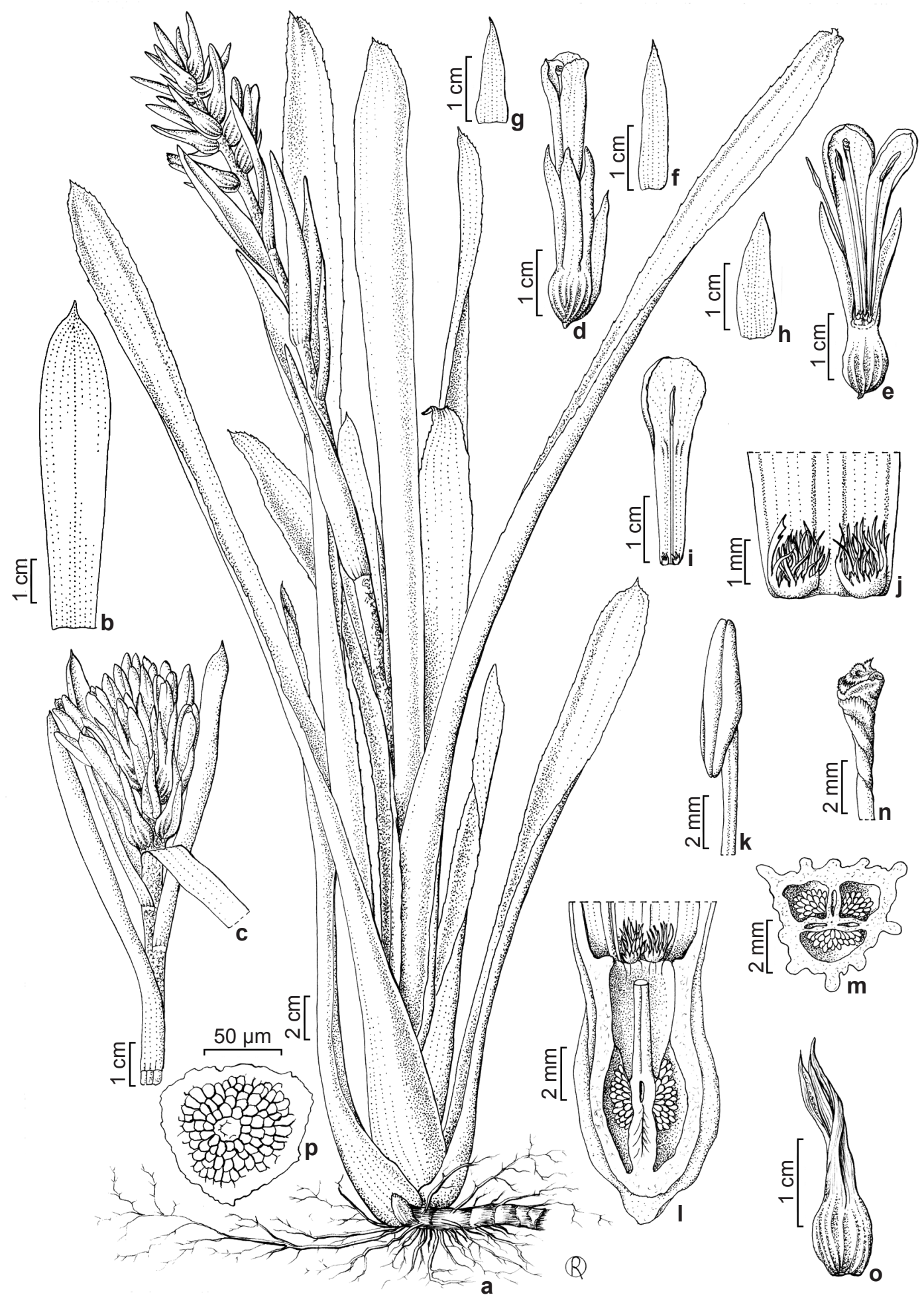

Figure 6-Quesnelia humilis Mez (Oliveira, F.M.C. 12) - a. habit; b. peduncle bracts; c. inflorescence; d. lateral view flower; e. open flower; f. lower floral bract; g. upper floral bract; h. sepal; i. petal; j. details of petal appendages and longitudinal callosities; $\mathrm{k}$. anthers; 1 . longitudinal section of ovary showing the ovules and epigeneus tube; $\mathrm{m}$. cross section of ovary and septal nectaries. n. stigma; 0 . fruits; p. peltate trichome with disc cells and ring cells arranged in irregular form. 
50-80 cm long, rosulate, imbricate, open rosette, forming a little tank at the basis, serrate at the margins, lepidote in both sides; the external 40 $\times 3 \mathrm{~cm}$, the internal 50-90 × $10 \mathrm{~cm}$; sheaths ca. $10 \times 5 \mathrm{~cm}$, oblong, lightly vinaceous; blades 45-80 × 3.2-4 cm, linear, mucrunate apex. Floral peduncle erect to curved, $65 \mathrm{~cm}$ long, 6 mm diameter, usually bigger than leaves, lightly lanuginous; peduncle bracts ca. $9.3 \times 1-2 \mathrm{~cm}$, ecliptics, acute apex, pink, membranaceous, much longer than internodes, tightly imbricate, evolving completely the peduncle, smooth margin. Inflorescence $9 \times 3.5 \mathrm{~cm}$, simple, spike, 10-20 polistic flowers; floral bracts dimorphic, the lower $3,2 \times 0,7 \mathrm{~cm}$, oblong-elliptic, exceeding the sepals length, pink, attenuated apex; the upper $1.9 \times 0.4 \mathrm{~cm}$, narrow-triangular, pink, pungent apex. Flowers sessile, ca. $4 \mathrm{~cm}$ long; sepals ca. $2 \times 0.5 \mathrm{~cm}$, oval, with hyaline margins at both sides, free to lightly conate at basis, pink, apiculate; petals ca. $3 \times 0.8 \mathrm{~cm}$, spatulate, free, erects, pink, blades with two pair of longitudinal callosities ca. $1.7 \mathrm{~cm}$ long, two basal petals appendages, fimbriated from the basis at the apex, emarginated apex, rounded, cuculate; stamens in two series, ca. $2.7 \mathrm{~cm}$ long, the first united at the petals by ca. $1.1 \mathrm{~cm}$, the second free, fillet with hyaline margins flattened, anthers ca. $6 \mathrm{~mm}$, lanceolate, dorsifixe; ovary $0.8 \times 0.5 \mathrm{~cm}$, oval, trine, pink to white, epigynous tube ca. 3 $\mathrm{mm}$, ovules numerous, stylet ca. $2.8 \mathrm{~cm}$, stigma conduplicate-spiral imbricate.

Material examined: Balsa Nova, Serra de São Luis do Purunã, fl., 25.III.1993, O.S. Ribas \& C. B.Poliquesi 512 (MBM); Serra de São Luis do Purunã, fl., 18.IX.1970, G. Hatschbach 24730 (MBM); Morro do Cristo, próximo ao Cristo, fl., 31.VIII.2011, F.M.C. Oliveira et al. 22 (HUPG); fl., 20.V.1986, R. Kummrow \& C.B.Poliquesi 2765 (MBM); fl., 15.III.2001, E.P.Santos, A.C.Cervi \& O. Ribas 946 (UPCB). Campo Largo, Serra de São Luis de Purunã, fl., 18.IX.1949, G. Hatschbach 1138 (MBM). Curitiba, fl., 15.IX.1968, J. Linderman \& H. Haas 2447 (MBM). Ponta Grossa, Cachoeira do Rio São Jorge, fl., 26.VIII.2010, F.M.C. Oliveira \& D. Kremer 1 (HUPG); fl., 21.VI.2011, F.M.C. Oliveira et al. 12 (HUPG); Cachoeira da Mariquinha, fl., 28.X.2010, F.M.C. Oliveira et al. 2 (HUPG); fl., 21.VI.2011, F.M.C. Oliveira et al. 13 (HUPG).

Additional material: BRAZIL. SÃO PAULO: São Miguel Arcanjo, Reserva Carlos Botelho, fl., 21.V.1977, H. Malcino 44 (MBM). Santo André, Estação biológica do Alto da Serra, fl., 1.VIII.1979, M. Kirizawa et al. 429 (SP); fl., 1.VIII.1979, M. Kirizawa et al. 436 (SP); fl., 27.VI.1983, T.P. Guerra et al. 37 (SP); fl., 28.III.1983, M. Kirizawa et al. 916 (SP); fl., 16.X.1984, M. Kirizawa et al. 1331 (SP); fl., 1.VIII.1979, C.F.Muniz et al. 6 (SP); fl., 17.IX.1987, A.L.M. Catharino 1150 (SP). Paranapiacaba, Estação Biológica Alto da Serra, fl., 27.VIII.1980, S.L. Jung, M.M.F.R. Melo \& M.G.L. Wanderley 7645 (SP); fl., 3.VII.1979, A. Custódio Filho 44 (SP); fl., 2.VIII.1977, O. Handro 2283 (SP); fl., 7.XII.1982, A. Custódio Filho \& M. Carra 1153 (SP); fl., 1.VIII.1979, A. Custódio Filho, M. Kirizawa \& S.F.C. Muniz 119 (SP). Ribeirão Pires, fl., 28.VII.1994, Edwall (SP12336).

Quesnelia humilis Mez is distributed on the Southeastern of Brazil (states of Rio de Janeiro and São Paulo) and southern Brazil (state of Paraná) on first and second plateaus in the region of Campos Gerais reaching the Serra de São Luis do Purunã in mixed rainforest. According to IUCN $Q$. humilis is endangered (EN) due to the decline in its natural population. In the state of Paraná, the populations of this species occur in private areas open to tourism, which leads to the degradation of the habitat. In the state of São Paulo, the species has also a worrisome status, where, according to Tamaki (2007) using the same evaluation criteria, it is considered vulnerable to extinction (VU). The author states that due to the decline in populations, stemming from the current fragmentation of the Atlantic Forest, this taxon and with other species of Bromeliaceae should have a priority status in terms of conservation and the author even suggests the conservation of the germplasm of these species. Blooms can be found from March to August; fruit found from July to September.

Quesnelia humilis is characterized by an open rosette with few loose leaves forming a tank. This mesophytic species is found, in Paraná state, exclusively in mixed rainforest as an epiphytic, humicolous or terricolous plant in wet, shady locations. Proença et al. (2007) cited $Q$. humilis as endemic to the state of São Paulo, but Glaziou collected the type material in 1887 in the state of Rio de Janeiro, broadening its natural geographic distribution. Martinelli et al. (2008) mentioned the species for the first time in the state of Paraná. The few previously collected specimens were mistakenly identified as Q imbricata L.B.Sm. and cited in Smith \& Downs (1979) and Reitz (1983). The analysis of different material from southeastern Brazil, including type material, demonstrates the smaller size of the plant (approximately $30 \mathrm{~cm}$ in height) in comparison to other plants found in the state of 
Paraná (southern Brazil), which were observed to be 50 to $80 \mathrm{~cm}$ high when blooming.

Wanderley \& Proença (2006) describe similarities between $Q$. violacea Wand. \& S.L. Proença found in São Paulo state and $Q$. humilis, differentiating the species by the floral bracts and number of flowers in the inflorescence. However, the morphological study of different specimens collected in the state of Paraná revealed the presence of intermediary characteristics between the two taxa. A study of these populations is needed in order to clarify the circunscription problems of these species.

\section{Acknowledgment}

The authors thank CAPES for the financial support.

\section{References}

Almeida, V.R.; Costa, A.F.; Mantovani, A.; Gonçalves-Esteves, V.; Arruda, R.C.O. \& Forzza, R.C. 2009. Morphological phylogenetics of Quesnelia (Bromeliaceae: Bromelioideae). Systematic Botany 34: 660-672.

Benzing, D.H. 2000. Bromeliaceae: profile of an adaptative radiation. Cambridge University Press, Cambridge. 690p.

BFG. 2015 Growing knowledge: An overview of seed plant diversity in Brasil. Rodriguésia 66: 1085-1113.

Brown, G.K. \& Gilmartin, A.J. 1989. Stigma types in Bromeliaceae. A systematic survey. Systematic Botany 14: 110-132.

Evans, M.E.; Jabaily, R.S.; Faria, A. P. G.; Sousa, L. O. F.; Wendt, T. \& Brown, G.K. 2015. Phylogenetic relationships in Bromeliaceae subfamily Bromelioideae based on chloroplast DNA sequence data. Systematic Botany 40: 116-128.

Fontoura, T.; Costa, A. \& Wendt, T. 1991. Preliminary checklist of the Bromeliaceae of Rio de Janeiro state, Brazil. Selbyana 12: 5-45.

Gaudichaud-Beaupré, C. 1842. Voyage autour du monde exécuté pendant les années 1836 et 1837 sur la corvette la Bonite. Atlas, Paris. 355p.

Givnish, T.J.; Barfuss, M.H.J.; Van EE, B.; Riina, R.; Schulte, K.; Horres, R.; Gonsiska, P.A.; Jabaily, R.S.; Crayn, D.M.; Smith, A.C.; Winter, K.; Brown, G.K.; Evans, T.M.; Holst, B.K.; Luther, H.; Till, W.; Zizka, G.; Berry, P.E. \& Sytsma, K.J. 2011. Phylogeny, adaptive radiation, and historical biogeography in Bromeliaceae: insights from an eight-locus plastid phylogeny. American Journal of Botany 98: 1-24.
Gonçalves, E.G. \& Lorenzi, H. 2011. Morfologia vegetal: organografia e dicionário ilustrado de morfologia das plantas vasculares. $2^{\mathrm{a}}$ ed. Instituto Plantarum de Estudos da Flora, São Paulo. 446p.

IUCN. IUCN: Red List of Threatened Species, 2010 Version 2010. Electronic Database. Available at $<$ http://www.iucnredlist.org/>. Access on 10 January 2012.

Judd, W.S.; Campbell, C.S.; Kellog, E.A.; Stevens, P.F. \& Donoghue, M.J. 2009. Sistemática vegetal: um enfoque filogenético. $3^{\mathrm{a}}$ ed. Artmed, São Paulo. 612p.

Lindman, C.A.M. 1891. Bromeliaceae herbarii regnelliani. I-Bromelieae. Konglia Svenka Vetenskaps-Akademiens Handligar 24: 19-24.

Luther, H. 2012. An alphabetical list of bromeliad binomials. $12^{\text {th }}$ ed. The Bromeliad Society International, The Marie Selby Botanical Gardens \& Bromeliad Society International, Sarasota. 44p.

Martinelli, G.; Vieira, C.M.; Gonzalez, M.; Leitman, P.; Piratininga, A.; Costa, A.F. \& Forzza, R.C. 2008. Bromeliaceae da Mata Atlântica brasileira: lista de espécies, distribuição e conservação. Rodriguésia 59: 209-258.

Mez, C. 1892. Bromeliaceae. In: Martius, C.F.P. von, Eichler, A.W. \& Urban, I. (eds.). Flora brasiliensis. München, Wien, Leipzig. N.3. Vol. 3, pp. 173-634.

Mez, C. 1896. Bromeliaceae. In: Candolle, A.L.P.P. de \& Candolle, A.C.P. (eds.). Monographiae phanerogamarum. G. Masson, Paris. 990p.

Mez, C. 1934-1935. Bromeliaceae. In: Engler, H.G.A. (ed.). Das flanzenreich... Wilhelm Engelman, Berlin. 32: 667p.

Proença, S.L.; Martins, E.M \& Wanderley, M.G.L. 2007. Quesnelia Gaudich. Bromeliaceae. In: Wanderley, M.G.L.; Shepherd, G.J.; Melhem, T.S. \& Giulietti, A.M. (org.). Flora fanerogâmica do estado de São Paulo. Instituto de Botânica, São Paulo. Vol. 5, pp. 1-476.

Radford, A.E,; Dickinson, W.C, Massey, J.R. \& Bell, C.R. 1974. Vascular plant systematics. Harper \& Row Publishers, New York. 891p.

Reitz, R. 1983. Bromeliáceas e a malária - bromélia endêmica. Flora Ilustrada Catarinense. 1: 1-559.

Schulte, K.; Barfuss, M.H.J. \& Zizka, G. 2009. Phylogeny of Bromelioideae (Bromeliaceae) inferred from nuclear and plastid DNA loci reveals the evolution of the tank habit within the subfamily. Molecular Phylogenetic Evolution 51: 327-339.

Smith, L.B. \& Downs, R.J. 1979. Bromelioideae (Bromeliaceae). Flora Neotropica. Vol. 14. Hafner Press, New York. Pp. 1493-2142. 
Stearn, W.T. 1983. Botanical Latin. David \& Charles, London. 566p.

Tardivo, R.C. 2014. Angiospermas- Bromeliaceae. In: Kaeler, M.; Goldenberg, R.; Evangelista, P.H.L.; Ribas, O.S.; Vieira, A.O.S. \& Hatschbach, G.G. (eds). Plantas vasculares do Paraná. Universidade Federal do Paraná, Curitiba. Pp 92-93.

Thiers, B. [continuously updated]. Index herbariorum: a global directory of public herbaria and associated staff. New York Botanical Garden's Virtual Herbarium. Available at $<$ http://sweetgum. nybg.org/ih/>. Access on 24 April 2015.

Vieira, C.M. 2006. Quesnelia Gaudich (Bromelioideae: Bromeliaceae) do estado do Rio de Janeiro, Brasil Pesquisas Botânicas 57: 7-102.

Wanderley, M.G.L \& Proença, S.L . 2006. Nova espécie de Quesnelia Gaudich. (Bromeliaceae) do estado de São Paulo, Brasil. Hoehnea 33: 111-113.

Wanderley, M.G.L; Shepherd, G.J; Melhem, T.S \& Giulietti, A.M. 2007. Flora fanerogâmica do estado de São Paulo. FAPESP, São Paulo. 476p.

Wawra, H. 1880. Les broméliacées brésiliennes découvertes en 1879 pendant le voyage des princes Auguste et Ferdinand de Saxe-Cobourg. Liège, Boverie. 76p.

Weberling, F. 1989. Morphology of flowers and inflorescences. Cambridge University Press, Cambridge, $405 \mathrm{p}$.

\section{List of collectors}

Barbosa, E. 819 (2). Catharino, A.L.M 1150 (3). Cordeiro, J. 1352 (2). Custódio Filho, A. 1671 (1), 44, 119, 1153 (3). Edwall s.n. (SP-12336) (3). Galvão, F. 50 (2). Guerra, T.P. 37 (3). Handro, O. 2283 (3). Hatschbach, G. 1016, 6725, 10004, 16831 (2), 1138 , 24730 (3). Hoehne, F.C. s.n. (SP -7542) (1). Jung, S.L. 7645 (3). Kirizawa, M. 1561 (1), 429, 436, 916 , 1331 (3). Kummrow, R. 2765 (3). Lattos, J. 10613 (1). Linderman, J. 2447 (3). Lopes, E.A. 82 (1). Malcino, H. 44 (3). Martinelli, G. 15031, 15897 (1). Moreira, B.A. s.n. (SP-382078) (1). Muniz, C.F. 6 (3). Oliveira, F.M.C. 14, 16 (1), 1, 2, 12, 13, 22 (3), 3, 6 (2). Poliquesi, C.B. 240 (2). Queiroz, L.P. de 4534 (1). Reitz, R. 6740, 10974 (2). Ribas, O.S. 512 (3). Rosa, N.A. 3944 (1). Santos, E.P. 476,705 (2), 946 (3). Seidel, L. 286 (1). Silva, J.M. 1499, 2014 (2). Smith, L.B. 8555 (2). Souza, L.R.M. 227 (1). Sugiyama, M. 559 (1). Tardivo, R.C. 169 (1). Tramujas, A.P. 179, 604 (2). Voltz 52 (2). Wanderley, M.G.L. 72, 2451 (1). 